\title{
Comparative analysis of two rivers infected with Didymosphenia geminata in southern Chile
}

\author{
Sandra Bravo ${ }^{1}$, Ken Whelan ${ }^{2}$, Karla Sambra ${ }^{1}$, María T. Silva ${ }^{3}$, Nike Ponce ${ }^{1}$ \& Patricio Campos ${ }^{1}$ \\ ${ }^{1}$ Instituto de Acuicultura, Universidad Austral de Chile, Puerto Montt, Chile \\ ${ }^{2}$ University College Dublin, Dublin, Ireland \\ ${ }^{3}$ Universidad San Sebastián, Puerto Montt, Chile \\ Corresponding author: Sandra Bravo (sbravo@uach.cl)
}

\begin{abstract}
The Puelo and Petrohué rivers were surveyed between April 2016 and February 2017 to assess the presence and seasonal abundance of Didymosphenia geminata in the wild aquatic systems of these two important rivers in southern Chile. Didymo was reported in the Puelo River in 2012, while it was declared absent from the Petrohué River before this study commenced in the fall of 2016. Results showed that cells of $D$. geminata were recorded in both rivers, in the Phytobenthos as well as in the water column. However, the classical mucilage which characterizes this plague was only recorded in one of the sampled rivers (Puelo). The mucilage was not recorded in any of the sections sampled in the Petrohué River, which was attributed to the high concentration of phosphorous present in the system. The concentration of phosphorous recorded throughout the study in the Puelo River was low. However, differences in the recorded presence or absence of D. geminata between sampling sites on the Petrohué River was mainly attributable to the availability of incident sunlight. This study records for the first time the presence of $D$. geminata in the Petrohue River.
\end{abstract}

Keywords: Didymosphenia geminata; seasonal abundance; phosphorous availability; aquatic invasions; Puelo River; Petrohué River; southern Chile

\section{INTRODUCTION}

Didymosphenia geminata (Lyngbye) was first discovered in the Faroe Islands by Lyngbye in 1817 and during the mid-1800s was reported for the first time from North America (Blanco \& Ector, 2009). Since then, D. geminata has expanded worldwide (Whitton $e t$ al., 2009) and blooms have been reported from Canada (Sherbot \& Bothwell, 1993; Kirkwood et al., 2007), Europe (Kawecka \& Sanecki, 2003), New Zealand (Kilroy et al., 2005; Kilroy \& Unwin, 2011) and South America (Segura, 2011).

Although D. geminata was reported for the first time from Chile in 1962 (Asprey et al., 1964; Rivera, 1983), there were no further reports of its presence until 2010, when the first $D$. geminata bloom was recorded

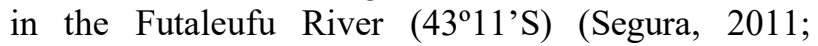
Beamud et al., 2013; Montecinos et al., 2014, 2016). This finding was attributed to the probable introduction of D. geminata through the presence of the organism on the contaminated equipment of recreational anglers, from countries where this plague is present. Since that time, D. geminata has spread quickly throughout the central-southern Chilean rivers, and today it is distributed from $36^{\circ}$ to $51^{\circ} \mathrm{S}$ (Díaz et al., 2011). However, not all rivers have been infected with the $D$. geminata mucilage. Its presence or absence has been associated with chemical and physical factors (Montecinos et al., 2016). D. geminata blooms are consistently associated with waters poor in phosphorous (Spaulding \& Elwell, 2007; Bothwell \& Spaulding, 2008; James et al., 2015), although other factors have been documented to be also important, such as exposure to adequate sunlight (James et al., 2014) and a stable substratum/flow regime (Kirkwood et al., 2009; Sastre et al., 2013).

Blooms occur when D. geminata cells form a large number of elongated stalks (Domozych et al., 2010). These primarily comprise sulfated polysaccharides and protein (Gretz, 2008) and can persist for up to two months

Corresponding editor: Loretto Contreras 
following peak production, even if the cells are removed from the stalks (Spaulding \& Elwell, 2007). However, there are some contaminated rivers and sections of rivers where mucilage has not been observed, prompting new questions aimed at identifying the factors that influence the presence or absence of $D$. geminata, and the conditions that encourage the diatom to bloom (Bothwell et al., 2012).

In Chile, there is a major concern regarding the spread of D. geminata, and since 2010 it is considered one of the more severe threats to river and stream ecosystems. Under certain environmental conditions, $D$. geminata can produce a large number of extracellular stalks, creating massive growths, covering the riverbed and significantly altering the environmental conditions in the affected waterbody (Ladrera et al., 2016, 2018). Dense growths of mucilage have also been shown to impact macroinvertebrate assemblages in the affected rivers negatively. Ladrera et al. (2015) reported that scrapers and others invertebrates living on the coarse substrate are especially affected by a dense mucilage, causing a significant disturbance of the composition and structure of macroinvertebrate community.

Because recreational angling is one of the important economic activities for southern Chile, this study was geared towards understanding which factors influence the presence or absence of the invasive $D$. geminata in the Puelo and Petrohué rivers, two important rivers for recreational fisheries. According to Beville et al. (2012), anglers were sensitive to the scale of Didymo infestation in New Zealand, causing a significant reduction in angler net benefit. In Chile, efforts to limit the spread of Didymo to other locations are the responsibility of Servicio Nacional de Pesca y Acuicultura (SERNAPESCA), the main fisheries authority in Chile. SERNAPESCA plays an important role in promoting and monitoring actions to stem the spread of the organism. Particular focus is placed on the role of recreational anglers in the spread of $D$. geminata, and very strict disinfection measures have been put in place. However, despite all this effort, the Didymo plague has a widespread distribution in southern Chile (Montecino et al., 2016).

\section{MATERIALS AND METHODS}

\section{Study area}

Between April 2016 and February 2017 four surveys were carried out in four sections of the Petrohue River (41 23 '12"S) and in four sections of the Puelo River (4139'51'S). Both rivers drain into Reloncavi Estuary and are separated by just $14 \mathrm{~km}$ (Fig. 1). Surveys were carried over the four seasons of the year; autumn (fall), winter, spring and summer. Hydro-morphological characteristics were visually recorded at each sampling site to explain the presence or absence of mucilage. It is important to note that the Petrohue River was severely impacted by the eruption of the Calbuco Volcano in April 2015, which resulted in major chemical and biological changes to one of the sections of river sampled (site B).

\section{Hydromorphology of the sections sampled in the Petrohué River}

The Petrohué River rises in Todos Los Santos Lake and runs $42 \mathrm{~km}$ downstream, before discharging into the Reloncavi Estuary. The Petrohué River drains approximately $463 \mathrm{~km}^{2}$, and the average stream gradient is around $0.44 \%$. The stream gradient in the first $16 \mathrm{~km}$ of the river is $1.12 \%$. It has a gradient of $0.12 \%$ after 28 $\mathrm{km}$ of river. The average flow is $280 \mathrm{~m}^{3} \mathrm{~s}^{-1}$, ranging between $147 \mathrm{~m}^{3} \mathrm{~s}^{-1}$ in summer and $437 \mathrm{~m}^{3} \mathrm{~s}^{-1}$ in winter.

\section{Site A}

$41^{\circ} 17^{\prime} 42.72^{\prime}$ 'S, $72^{\circ} 24^{\prime} 14.70^{\prime \prime} \mathrm{W}$. This sector of $9.0 \mathrm{~km}$ displays strong currents. It is located in a very isolated and remote zone, surrounded by dense vegetation, with an average slope of $8.4 \%$. The location where the samples were taken has a depth ranging between 1.1 and $3.0 \mathrm{~m}$ and has a current velocity ranging between 1.1 and $1.2 \mathrm{~m} \mathrm{~s}^{-1}$ (Table 1).

\section{Site B}

$41^{\circ} 15^{\prime} 6.36^{\prime \prime} \mathrm{S}, 72^{\circ} 26^{\prime} 22.62^{\prime \prime} \mathrm{W}$. This site has a depth ranging between 1.2 and $1.5 \mathrm{~m}$ and a current velocity ranging between 1.6 and $2.1 \mathrm{~m} \mathrm{~s}^{-1}$ (Table 1). The riverbed comprises both sand and gravel and drains from the mountains located to the east of Calbuco Volcano. The first $14 \mathrm{~km}$ of the river has a slope of $3.6 \%$, and over the last $3 \mathrm{~km}$, the slope of the river is $0.5 \%$. The river mouth is $400 \mathrm{~m}$ wide and flows over a sizeable aquatic plain, consisting of meanders and sand shoals.

\section{Site $\mathbf{C}$}

$41^{\circ} 10^{\prime} 47.34^{\prime \prime} \mathrm{S}, 72^{\circ} 27^{\prime} 33.36^{\prime \prime} \mathrm{W}$. This site is a $2.1 \mathrm{~km}$ long creek and has a slope of $1.3 \%$. A dense native forest surrounds it. The bed is sandy, with muddy margins and shorelines. It has a depth ranging between 0.7 and $1.2 \mathrm{~m}$, and a current velocity ranging between 0.9 and $1.7 \mathrm{~m} \mathrm{~s}^{-1}$ (Table 1).

\section{Site D}

$41^{\circ} 14^{\prime} 37.50^{\prime}$ 'S, $72^{\circ} 26^{\prime} 44.64^{\prime \prime} \mathrm{W}$. This is a $10 \mathrm{~km}$ river that drains remote mountainous and hillsides terrain 


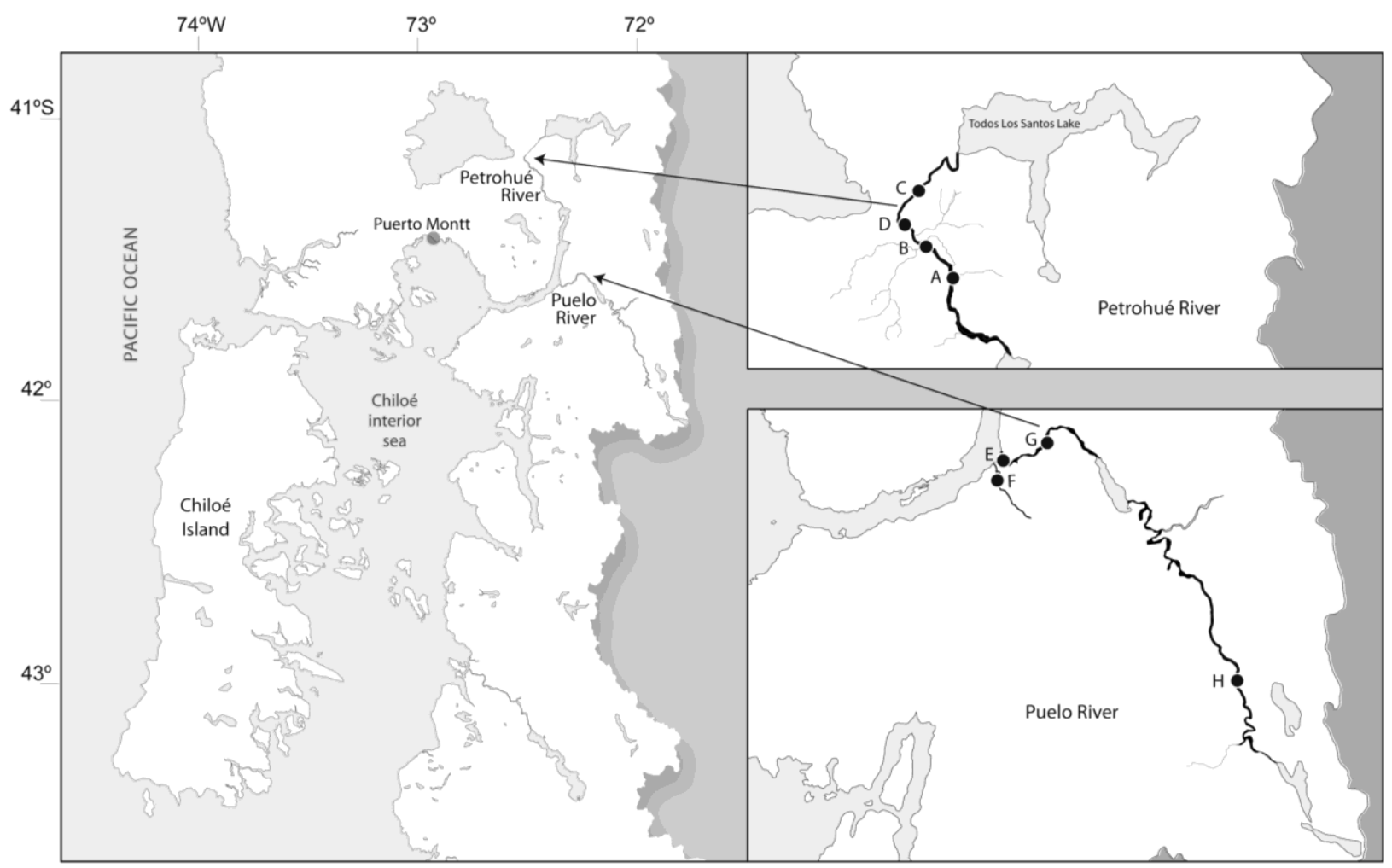

Figure 1. Map showing the sampling sectors in Petrohué River (A, B, C, D) and Puelo River (E, F, G, H).

Table 1. Hydrographic parameters (mean \pm SD) by sector, Petrohué River.

\begin{tabular}{lccccc}
\hline \multirow{2}{*}{ Parameters } & \multirow{2}{*}{ Statistics } & \multicolumn{4}{c}{ Sector } \\
\cline { 3 - 6 } & & $\mathrm{A}$ & $\mathrm{B}$ & $\mathrm{C}$ & $\mathrm{D}$ \\
\hline \multirow{2}{*}{ Temperature $\left({ }^{\circ} \mathrm{C}\right)$} & Mean $\pm \mathrm{SD}$ & $11.8 \pm 1.3$ & $12.1 \pm 1.6$ & $12.3 \pm 1.3$ & $10.2 \pm 1.4$ \\
& Range & $10.2-13.0$ & $9.7-14.1$ & $11-14.4$ & $8.6-12.3$ \\
\hline \multirow{2}{*}{ Oxygen $\left(\mathrm{mg} \mathrm{L}^{-1}\right)$} & Mean $\pm \mathrm{SD}$ & $10.4 \pm 1.0$ & $9.1 \pm 2.2$ & $9.0 \pm 0.7$ & $10.1 \pm 1.8$ \\
& Range & $8.9-11.6$ & $6.1-11.5$ & $8.2-9.7$ & $7.9-12.4$ \\
\hline \multirow{2}{*}{$\mathrm{pH}$} & Mean $\pm \mathrm{SD}$ & $7.8 \pm 0.9$ & $6.9 \pm 0.7$ & $7.5 \pm 0.6$ & $7.2 \pm 0.8$ \\
& Range & $6.6-8.9$ & $6.0-7.6$ & $6.8-8.2$ & $5.8-7.9$ \\
\hline Conductivity & Mean $\pm \mathrm{SD}$ & $90.6 \pm 22.7$ & $106.2 \pm 14.6$ & $73.9 \pm 18.7$ & $96.0 \pm 9.2$ \\
$\left(\mu \mathrm{S} \mathrm{cm}{ }^{-1}\right)$ & Range & $58.6-108.7$ & $91.0-125.3$ & $58.6-98.5$ & $86.4-106.5$ \\
\hline \multirow{2}{*}{ Current velocity $\left(\mathrm{m} \mathrm{s}^{-1}\right)$} & Mean $\pm \mathrm{SD}$ & $1.2 \pm 0.1$ & $1.8 \pm 0.2$ & $1.4 \pm 0.4$ & $1.2 \pm 0.2$ \\
& Range & $1.1-1.2$ & $1.6-2.1$ & $0.9-1.7$ & $1.0-1.4$ \\
\hline \multirow{2}{*}{ Depth $(\mathrm{m})$} & Mean $\pm \mathrm{SD}$ & $1.7 \pm 0.9$ & $1.3 \pm 0.1$ & $1.0 \pm 0.2$ & $0.7 \pm 0.3$ \\
& Range & $1.1-3.0$ & $1.2-1.5$ & $0.7-1.2$ & $0.4-1.0$ \\
\hline \multirow{2}{*}{ Turbidity $(\mathrm{NTU})$} & Mean $\pm \mathrm{SD}$ & $5.0 \pm 3.8$ & $34.9 \pm 32.4$ & $0.3 \pm 0.1$ & $2.2 \pm 1.7$ \\
& Range & $0.5-9.8$ & $6.7-85.0$ & $0.2-0.4$ & $0.8-4.0$ \\
\hline
\end{tabular}

( $11.4 \%$ slope). The final $2.0 \mathrm{~km}$ stretch ( $1.8 \%$ slope), is an area where the river erodes and deposits much of its sediment load. It is surrounded by dense forest and abundant vegetation. The sampling site has an average depth of between 0.4 and $1.0 \mathrm{~m}$, and the current velocity ranges between 1.0 and $1.4 \mathrm{~m} \mathrm{~s}^{-1}$ (Table 1 ).

\section{Hydromorphology of the sectors sampled in the Puelo River}

The Puelo River is a watershed shared between Chile and Argentina. It rises in Puelo Lake, which is located on the border with Argentina and runs for $100 \mathrm{~km}$ downstream until it discharges into the Reloncavi 
Estuary. The Puelo River drains approximately 3,094 $\mathrm{km}^{2}$, and the average stream gradient is around $0.2 \%$. The average flow is $670 \mathrm{~m}^{3} \mathrm{~s}^{-1}$ and ranges between 415 $\mathrm{m}^{3} \mathrm{~s}^{-1}$ in summer and $92,020 \mathrm{~m}^{3} \mathrm{~s}^{-1}$ in winter.

\section{Site E}

$41^{\circ} 37^{\prime} 32.58^{\prime \prime} \mathrm{S} ; 7^{\circ} 14^{\prime} 48.71^{\prime \prime} \mathrm{W}$. This site is located downstream of Tagua-Tagua Lake. This area is close to small towns and tourist areas. It has easy access by rural road and is an important angling area. This stretch of the river receives water from a range of sub-catchments. The sampling site is surrounded by vegetation and native forest. The current velocity ranges between 1.2 and $2.3 \mathrm{~m} \mathrm{~s}^{-1}$, and the average depth ranges between 2.6 and $3.6 \mathrm{~m}$ (Table 2).

\section{Site F}

$41^{\circ} 41^{\prime} 45.09^{\prime \prime} \mathrm{S}, 72^{\circ} 17^{\prime} 24.26^{\prime \prime} \mathrm{W}$. This site is $28 \mathrm{~km}$ long. It drains remote mountainous and hillsides terrain ( $7.6 \%$ slope), including the eastern slope of the Yates Volcano. The upper and medium basin is a mountainous area with high erosive potential, where the river erodes and deposits part of its sediment load. In the lower basin (1.1\% slope), the river flows through relatively flat areas, forming meanders, sand shoals and islands of deposited sediment. The riverbed contains pebbles, gravel and boulders. The sampling site has a depth ranging between 2.3 and $3.1 \mathrm{~m}$ and has a current velocity ranging between 1.0 and $2.5 \mathrm{~m} \mathrm{~s}^{-1}$ (Table 2).

\section{Site G}

$41^{\circ} 37^{\prime} 0.11^{\prime \prime} \mathrm{S}, 72^{\circ} 12^{\prime} 11.71^{\prime \prime} \mathrm{W}$. This zone is isolated and very difficult to access. It is located $4.5 \mathrm{~km}$ from Tagua-Tagua Lake. This zone has a rocky bed, dominated by boulders and gravel. The depth ranges between 2.7 and $3.2 \mathrm{~m}$, and the current velocity ranges between 1.4 and $2.4 \mathrm{~m} \mathrm{~s}^{-1}$ (Table 2). It is surrounded by a mass of dense vegetation and native forest.

\section{Site $\mathbf{H}$}

$41^{\circ} 56^{\prime} 1.56^{\prime}$ 'S, $71^{\circ} 55^{\prime} 43.60^{\prime \prime} \mathrm{W}$. Native vegetation and a dense native forest surround this section of the river. The riverbed comprises pebble-like rocks, with a depth ranging between 1.7 and $2.3 \mathrm{~m}$. The current and velocity range between 0.8 and $2.3 \mathrm{~m} \mathrm{~s}^{-1}$ (Table 2).

\section{Didymo sampling procedures}

Sampling for the Didymosphenia geminata cells suspended in the water column was carried out using a phytoplankton net with a $32 \mu \mathrm{m}$ mesh size, adapted for Didymo collection. The net was left to drift horizontally for $10 \mathrm{~min}$ under the water surface (Wells et al., 2007; Díaz et al., 2011). The collected material was then fixed with 2\% Lugol's solution (Throndsen, 1978).
Phytobenthos was sampled from five stones suspected of carrying D. geminata. Each stone was scraped with a disposable wooden spatula. All scrapings from the five stones were stored together and fixed with $2 \%$ Lugol's solution. Samples were stored at ambient temperature and analysed a week after sampling.

\section{Didymo samples processing}

A $1 \mathrm{~mL}$ subsample from each site was processed following the methodology recommended by Patrick \& Reimer (1966) and Battarbee (1986), using a Sedgwick Rafter chamber. Presence of D. geminata was determined qualitatively by scanning the chamber under an inverted optical microscope (Olympus BX40) at 200400x. A minimum of 200 fields was analysed, and cells were quantified in random transects. Afterward, the abundance of $D$. geminata was calculated.

\section{Environmental and water chemical variables}

Samples of water for chemical analysis were collected from each sector in both rivers (Tables 1-2), which were analyzed by a local certified laboratory (ANAM) using APHA Standard Methods (2005). Also, dissolved oxygen, temperature and conductivity were recorded in the field using multi-parameter equipment (Hanna, HI9835). Hanna, HI991002, was used to measure $\mathrm{pH}$. Water velocity was estimated manually with a float, and water depth was measured.

\section{Macroinvertebrate sampling}

Samples of the macroinvertebrate assemblages were collected using a $500 \mu \mathrm{m}$ Surber net in each sector. Samples were preserved in 95\% ethanol and taken to the laboratory to be identified. The identification of macroinvertebrates was made to the order level using stereoscopic microscopy and taxonomical keys (McCafferty, 1981; Palma, 2013).

\section{Data analysis}

Abiotic variables and water quality were seasonally analyzed from the four selected sectors in the two rivers (Petrohué and Puelo) to assess the factors associated with the presence or absence of $D$. geminata. The nonparametric Mann Whitney test was used for evaluation of abnormality of the variables using the Shapiro Wilks test. The Spearman rank order correlation coefficient was used to assess the relationship between the abundance of macroinvertebrates and the abundance of D. geminata.

Biosecurity procedures were applied to avoid the spread of D. geminata between sites and rivers, following the recommendations established by the Subsecretaría de Pesca y Acuicultura de Chile (Díaz et al., 2011). All material and equipment were rigorously cleaned between samplings, washed and disinfected. 
Table 2. Parameters (mean \pm SD) by sector, Puelo River.

\begin{tabular}{lccccc}
\hline \multirow{2}{*}{ Parameters } & \multirow{2}{*}{ Statistics } & \multicolumn{4}{c}{ Sector } \\
\cline { 3 - 6 } & & $\mathrm{E}$ & $\mathrm{F}$ & $\mathrm{G}$ & $\mathrm{H}$ \\
\hline \multirow{2}{*}{ Temperature $\left({ }^{\circ} \mathrm{C}\right)$} & Mean $\pm \mathrm{SD}$ & $12.4 \pm 3.9$ & $12.5 \pm 4.6$ & $10.6 \pm 3.7$ & $10.3 \pm 3.1$ \\
& Range & $8.6-16.8$ & $7.6-18.1$ & $5.9-14.5$ & $7.5-14.1$ \\
\hline \multirow{2}{*}{ Oxygen $\left(\mathrm{mg} \mathrm{L}^{-1}\right)$} & Mean $\pm \mathrm{SD}$ & $8.7 \pm 1.1$ & $8.6 \pm 0.4$ & $10.3 \pm 1.0$ & $9.3 \pm 1.8$ \\
& Range & $7.2-9.7$ & $8.3-9.1$ & $9.2-11.5$ & $7.2-11.5$ \\
\hline \multirow{2}{*}{$\mathrm{pH}$} & Mean $\pm \mathrm{SD}$ & $5.8 \pm 0.6$ & $6.1 \pm 0.3$ & $6.0 \pm 0.8$ & $6.3 \pm 0.5$ \\
& Range & $5.0-6.3$ & $6.0-6.5$ & $5.0-7.0$ & $6.0-7.0$ \\
\hline \multirow{2}{*}{ Conductivity $\left(\mu \mathrm{S} \mathrm{cm}^{-1}\right)$} & Mean $\pm \mathrm{SD}$ & $67.1 \pm 22.6$ & $46.8 \pm 7.7$ & $121.6 \pm 23.9$ & $42.4 \pm 2.1$ \\
& Range & $42.2-88.5$ & $35.6-53.1$ & $100.2-146.0$ & $40.0-44.8$ \\
\hline \multirow{2}{*}{ Current Velocity $\left(\mathrm{m} \mathrm{s}^{-1}\right)$} & Mean $\pm \mathrm{SD}$ & $1.9 \pm 0.5$ & $2.0 \pm 0.7$ & $1.9 \pm 0.5$ & $1.7 \pm 0.7$ \\
& Range & $1.2-2.3$ & $1.0-2.5$ & $1.4-2.4$ & $0.8-2.3$ \\
\hline \multirow{2}{*}{ Depth $(\mathrm{m})$} & Mean $\pm \mathrm{SD}$ & $3.0 \pm 0.4$ & $2.7 \pm 0.3$ & $3.0 \pm 0.2$ & $2.0 \pm 0.3$ \\
& Range & $2.6-3.6$ & $2.3-3.1$ & $2.7-3.2$ & $1.7-2.3$ \\
\hline \multirow{2}{*}{ Turbidity $(\mathrm{NTU})$} & Mean $\pm \mathrm{SD}$ & $3.5 \pm 2.5$ & $1.7 \pm 2.3$ & $8.3 \pm 8.5$ & $4.9 \pm 4.8$ \\
& Range & $0.6-6.0$ & $0.3-5.1$ & $1.0-19$ & $0.6-10$ \\
\hline
\end{tabular}

\section{RESULTS}

\section{Sampling sites hydro-morphological features}

The Puelo River is wide with a high water velocity and depth, highly influenced by the intensity of sunlight. In contrast, the sectors analysed in the Petrohué River were narrow, shallow and less exposed to light because of the dense forest covering along the riverbanks. A wide range of temperature was recorded from the two rivers, but differences were not significantly different (Tables 3-4).

There were no significant differences in recorded oxygen levels between the two rivers, although the higher oxygen levels were consistently recorded from the Petrohué River (Table 1).

Differences were recorded in $\mathrm{pH}$, with higher levels in the Petrohué River (Table 4). In both rivers, the conductivity showed a wide range of values, with higher values for the Petrohué River (Tables 1-2). Also, the water velocity and depth were higher in the Puelo River, with significant differences between both rivers (Table 4). Turbidity levels were higher in the Petrohué than in the Puelo, mainly along the section impacted by the volcanic eruption (Table 1).

\section{Didymosphenia geminata abundance}

Mucilage was not observed from any of the sections sampled in the Petrohué River. However, D. geminata cells were recorded in the water column in two of the four analysed sections, with an abundance ranging from 106 cell $\mathrm{L}^{-1}$ in winter and 4,800 cell L $\mathrm{L}^{-1}$ in summer (Fig. 2a). In the phytobenthos, D. geminata was recorded in three of the four analyzed river sections, with an abundance ranging between 354 cell L$^{-1}$ in winter and
3,121 cell L $\mathrm{L}^{-1}$ in summer (Fig. 2b). D. geminata was not recorded in both the column water and the phytobenthos in one of the four sampled sectors in the Petrohué River (Fig. 2). The abundance of D. geminata in the water column, sampled in Puelo River, ranged between 2,589 cell $\mathrm{L}^{-1}$ in autumn and 934,567 cell L-1 in summer (Fig. 3a). In the phytobenthos, it ranged between 2,900 cell $\mathrm{L}^{-1}$ in winter and around 2.5 million cell $\mathrm{L}^{-1}$ in autumn (Fig. 3b). The presence of mucilage was recorded in all sectors and the four seasons of the year.

\section{Mineral concentration in the sampling sites}

In comparison to the Puelo River results, the water analysis of the Petrohue River showed consistently higher values for alkalinity $\left(\mathrm{CaCO}_{3}\right)$ (Fig. 4), phosphorous ( $\left.>0.02 \mathrm{mg} \mathrm{L}^{-1}\right)$ (Fig. 5) and silicate (>5 mg $\mathrm{L}^{-1}$ ) (Fig. 6), with significance differences (Table 4). The values for nitrite; nitrate and total nitrogen were higher in the Petrohué River than in the Puelo River (Table 4).

Concentrations of iron were higher in the Petrohué River, mainly in sector B (Fig. 7), that was severely impacted by the eruption of the Calbuco Volcano in April 2015. However, no significant differences were recorded between both rivers (Table 3 ).

\section{Macroinvertebrates community}

In the Petrohué River, there was no correlation between macroinvertebrate abundance and the abundance of $D$. geminata cells in the phytobenthos $\left(r_{\mathrm{s}}=0.088 ; P=\right.$ 0.754) (Fig. 8). Neither was there a correlation found in the Puelo River $\left(r_{\mathrm{s}}=0.067 ; P=0.805\right)$ (Fig. 9), where mucilage was recorded from all sampling sites. 
Table 3. Comparison of parameters (mean \pm SD), at sites with the presence or absence of Didymosphenia geminata cells in Petrohué River, southern Chile. *Significant values $(P<0.05)$.

\begin{tabular}{|c|c|c|c|c|c|c|c|}
\hline \multirow{2}{*}{ Parameter } & & \multicolumn{2}{|c|}{ D. geminata absent } & \multicolumn{2}{|c|}{ D. geminata present } & \multirow{2}{*}{$\mathrm{Z}$} & \multirow{2}{*}{$P$-valor } \\
\hline & & Mean \pm SD & Range & Mean \pm SD & Range & & \\
\hline Temperature & ${ }^{\circ} \mathrm{C}$ & $12.0 \pm 1.5$ & $9.7-14.4$ & $11.4 \pm 1.6$ & $8.6-14.1$ & -0.72 & 0.475 \\
\hline Oxygen & $\mathrm{mg} \mathrm{L}^{-1}$ & $9.5 \pm 1.2$ & $8.2-11.5$ & $9.7 \pm 1.8$ & $6.1-12.4$ & -0.56 & 0.579 \\
\hline $\mathrm{pH}$ & & $7.4 \pm 0.6$ & $6.6-8.2$ & $7.3 \pm 0.9$ & $5.8-8.9$ & -0.48 & 0.634 \\
\hline Conductivity & $\mu \mathrm{S} \mathrm{cm}-1$ & $79.1 \pm 19.9$ & $58.6-100.0$ & $97.4 \pm 17.2$ & $58.6-125.3$ & -1.70 & 0.089 \\
\hline Water velocity & $\mathrm{m} \mathrm{s}^{-1}$ & $1.5 \pm 0.5$ & $0.9-2.1$ & $1.3 \pm 0.3$ & $1.0-1.9$ & -0.85 & 0.441 \\
\hline Depth & M & $1.1 \pm 0.3$ & $0.7-1.5$ & $1.2 \pm 0.7$ & $0.4-3.0$ & -0.40 & 0.690 \\
\hline Turbidity & NTU & $12.6 \pm 31.9$ & $0.2-85.0$ & $9.5 \pm 13.3$ & $0.5-45.0$ & -2.26 & $0.024 *$ \\
\hline Alkalinity & $\mathrm{mg} \mathrm{L}^{-1}$ & $34.0 \pm 2.0$ & $32.0-36.0$ & $27.1 \pm 8.4$ & $17-38.0$ & -0.94 & 0.347 \\
\hline Phosphorus & $\mu \mathrm{g} \mathrm{L}^{-1}$ & $75.7 \pm 50.3$ & $1.0-132.0$ & $31.1 \pm 35.2$ & $0.4-130.0$ & -2.01 & $0.044 *$ \\
\hline Silicate & $\mathrm{mg} \mathrm{L}^{-1}$ & $10.5 \pm 2.6$ & $7.6-14.3$ & $8.3 \pm 3.1$ & $5.0-14.1$ & -1.87 & 0.062 \\
\hline Nitrite & $\mu \mathrm{g} \mathrm{L}^{-1}$ & $29.1 \pm 53.3$ & $9.0-50.0$ & $23.2 \pm 35.6$ & $9.0-120.0$ & -0.16 & 0.875 \\
\hline Nitrate & $\mu \mathrm{g} \mathrm{L}^{-1}$ & $46.0 \pm 0.0$ & - & $305.5 \pm 493.5$ & $46.0-1400.0$ & -1.47 & 0.143 \\
\hline Total nitrogen & $\mu \mathrm{g} \mathrm{L}^{-1}$ & $51.9 \pm 55.3$ & $0.0-149.0$ & $279.8 \pm 501.0$ & $9.0-1400.0$ & -0.39 & 0.698 \\
\hline Iron & $\mu \mathrm{g} \mathrm{L}^{-1}$ & $177.1 \pm 335.9$ & $20.0-920.0$ & $318 \pm 316.1$ & $20.0-960.0$ & -1.83 & 0.068 \\
\hline Aluminum & $\mu \mathrm{g} \mathrm{L}^{-1}$ & $277.9 \pm 486.5$ & $6.8-280$ & $372.1 \pm 454.8$ & $13.0-1260.0$ & -1.23 & 0.217 \\
\hline Cooper & $\mu \mathrm{g} \mathrm{L}^{-1}$ & $2.8 \pm 3.0$ & $1.6-9.6$ & $4.2 \pm 4.4$ & $1.0-14.0$ & -0.18 & 0.858 \\
\hline Zinc & $\mu \mathrm{g} \mathrm{L}^{-1}$ & $1.7 \pm 0.8$ & $0.0-2.1$ & $2.8 \pm 4.6$ & $0.0-19.0$ & -0.52 & 0.606 \\
\hline
\end{tabular}

Table 4. Comparison of parameters (mean $\pm \mathrm{SD}$ ), with the presence or absence of Didymosphenia geminata mucilage in Petrohué River (absent) and Puelo River (present), southern Chile. *Significant values $(P<0.05)$.

\begin{tabular}{|c|c|c|c|c|c|c|c|}
\hline \multirow{2}{*}{ Parameter } & & \multicolumn{2}{|c|}{ Petrohué River } & \multicolumn{2}{|c|}{ Puelo River } & \multirow[t]{2}{*}{$\mathrm{Z}$} & \multirow[t]{2}{*}{$P$-valor } \\
\hline & & Mean \pm SD & Range & Mean \pm SD & Range & & \\
\hline Temperature & ${ }^{\circ} \mathrm{C}$ & $11.6 \pm 1.5$ & $8.6-14.4$ & $11.4 \pm 3.6$ & $5.9-18.1$ & -0.41 & 0.679 \\
\hline Oxygen & $\mathrm{mg} \mathrm{L}^{-1}$ & $9.7 \pm 1.6$ & $6.1-12.4$ & $9.2 \pm 1.2$ & $7.2-11.5$ & -1.15 & 0.251 \\
\hline $\mathrm{pH}$ & & $7.3 \pm 0.8$ & $5.8-8.9$ & $6.1 \pm 0.5$ & $5.0-7.0$ & -4.07 & $0.000 *$ \\
\hline Conductivity & $\mu \mathrm{S} \mathrm{cm}-1$ & $91.7 \pm 19.4$ & $58.6-125.3$ & $69.5 \pm 35.9$ & $35.6-146.0$ & -2.49 & $0.013^{*}$ \\
\hline Water velocity & $\mathrm{m} \mathrm{s}^{-1}$ & $1.4 \pm 0.3$ & $0.9-2.1$ & $1.9 \pm 0.5$ & $0.8-2.5$ & -2.40 & $0.017 *$ \\
\hline Depth & M & $1.2 \pm 0.6$ & $0.4-3.0$ & $2.6 \pm 0.5$ & $1.7-3.6$ & -4.40 & $0.000 *$ \\
\hline Turbidity & NTU & $10.6 \pm 20.9$ & $0.2-85.0$ & $4.6 \pm 5.2$ & $0.3-19.0$ & -0.14 & 0.886 \\
\hline Alkalinity & $\mathrm{mg} \mathrm{L}^{-1}$ & $28.6 \pm 8$ & $17.0-38.0$ & $13.5 \pm 4.1$ & $5.0-17.0$ & -3.55 & $0.000 *$ \\
\hline Phosphorus & $\mu \mathrm{g} \mathrm{L}^{-1}$ & $45.3 \pm 44.8$ & $0.4-132.0$ & $7.8 \pm 9.8$ & $0.4-32.0$ & -3.09 & $0.002 *$ \\
\hline Silicate & $\mathrm{mg} \mathrm{L}^{-1}$ & $9.0 \pm 3.1$ & $5.0-14.3$ & $3.2 \pm 1.0$ & $2.1-5.7$ & -4.65 & $0.000 *$ \\
\hline Nitrite & $\mu \mathrm{g} \mathrm{L}^{-1}$ & $25.1 \pm 40.8$ & $9.0-150.0$ & $9 \pm 0.0$ & - & -1.78 & 0.076 \\
\hline Nitrate & $\mu \mathrm{g} \mathrm{L}^{-1}$ & $222.9 \pm 421.5$ & $46.0-1400.0$ & $43.4 \pm 10.4$ & $4.6-46.0$ & -2.06 & $0.039 *$ \\
\hline Total nitrogen & $\mu \mathrm{g} \mathrm{L}^{-1}$ & $207.3 \pm 424.3$ & $0.0-1400.0$ & $38.6 \pm 14.2$ & $10.0-64.0$ & -0.67 & 0.505 \\
\hline Iron & $\mu \mathrm{g} \mathrm{L}^{-1}$ & $273.2 \pm 321.5$ & $20-960$ & $116.3 \pm 105.8$ & $20.0-470.0$ & -0.42 & 0.677 \\
\hline Aluminium & $\mu \mathrm{g} \mathrm{L}^{-1}$ & $342.1 \pm 455.6$ & $6.8-1280.0$ & $157.3 \pm 159.4$ & $12.4-516.0$ & -0.21 & 0.836 \\
\hline Cooper & $\mu \mathrm{g} \mathrm{L}^{-1}$ & $3.7 \pm 4.0$ & $1.0-14.0$ & $1.9 \pm 0.5$ & $1.6-3.1$ & -0.35 & 0.758 \\
\hline Zinc & $\mu \mathrm{g} \mathrm{L}^{-1}$ & $2.5 \pm 3.8$ & $0.0-19.0$ & $2.2 \pm 2.0$ & $0.0-7.2$ & -1.20 & 0.229 \\
\hline
\end{tabular}

\section{DISCUSSION}

According to the literature, blooms of Didymosphenia geminata mainly affect oligotrophic rivers (Bothwell \& Kilroy, 2011; Sundareshwar et al., 2011). Mucilage is typically present where nutrient levels are low, particularly, where low concentrations of phosphorus are present. The nutrient-poor Puelo River contained high concentrations of D. geminata, both in the water column and in the phytobenthos. Although higher phosphorous levels were recorded in the Petrohué River and no mucilage was found to be present. D. geminata cells were recorded both in the water column and in the phytobenthos in two of the four sections under study (B and D). It may well indicate that a range of other factors, besides phosphorous, are involved in the blooming of $D$. geminata cells.

Bothwell et al. (2014) established that blooms occur when $D$. geminata does not have access to sufficient amounts of phosphorous, and Whitton \& Ellwood (2008) demonstrated that D. geminata is highly efficient in the use of phosphorus, using enzymes such as phosphate alkaline. On the other hand, it is suggested that mucilaginous structures are involved in the efficient 


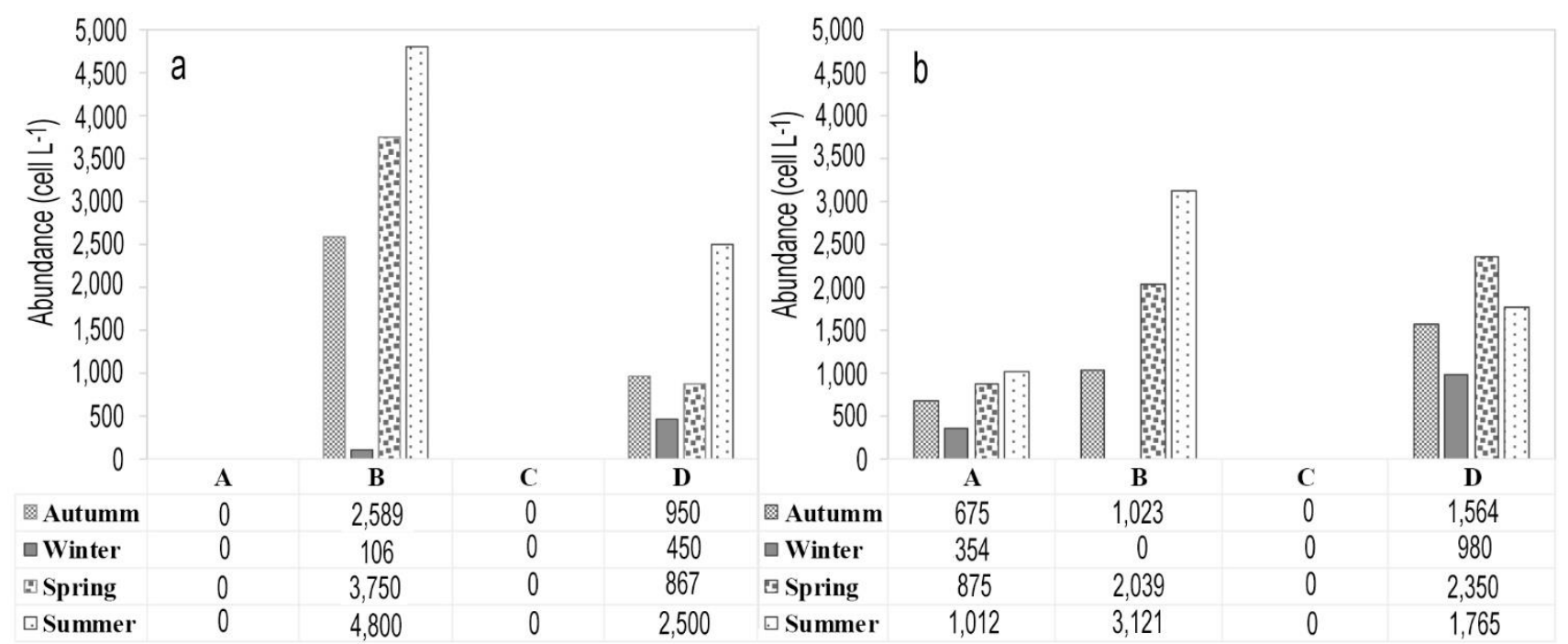

Figure 2. Abundance Didymosphenia geminata cells by sector and season in Petrohué River. a) Column water, b) phytobenthos. Sampled sectors: A, B, C, D.
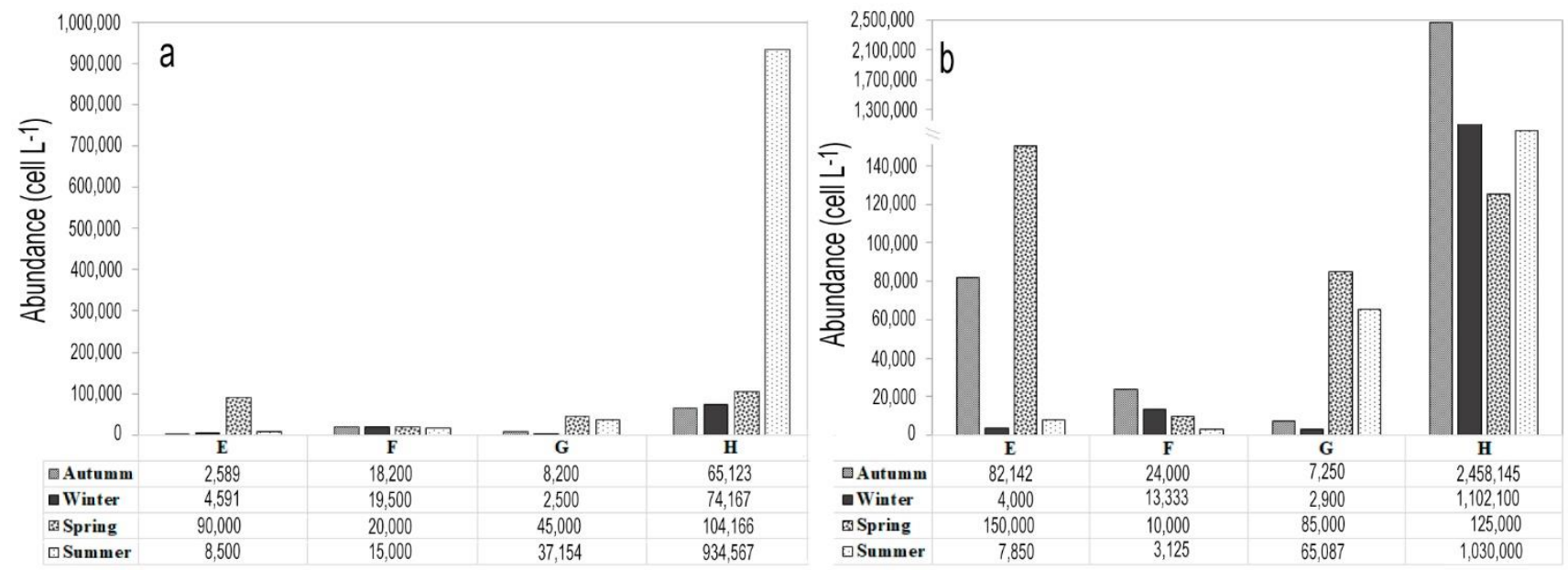

Figure 3. Abundance Didymosphenia geminata cells by sector and season in Puelo River. a) Column water, b) phytobenthos. Sampled sectors: E, F, G, H.

use of nutrients (Kirkwood et al., 2007), including the direct uptake of phosphorus (Whitton \& Ellwood, 2008), in the presence of iron (Sundareshwar et al., 2011). However, in this study, the main differences in the concentration of iron were recorded only in sector $\mathrm{B}$, which was highly impacted by the eruption of the Calbuco Volcano, and this is coincident with that reported by Bothwell et al. (2012), who demonstrated that iron enrichment has no effect on the phosphorus uptake by $D$. geminata colonies.

Spaulding \& Elwell (2007) reported that D. geminata occurred most frequently in freshwater with a low concentration of phosphorus $\left(<2 \mu \mathrm{g} \mathrm{L}^{-1}\right)$ and nitrate $\left(<1 \mathrm{mg} \mathrm{L}^{-1}\right)$, although it has been found in waters with phosphorus concentrations of $>10 \mu \mathrm{g} \mathrm{L}^{-1}$. In this study, the phosphorous values ranged between 0.4 and $32 \mu \mathrm{g} \mathrm{L}{ }^{-1}$ in the Puelo River, while in Petrohué River, the concentrations ranged between 0.4 and $130 \mu \mathrm{g} \mathrm{L}^{-1}$ (Table 3). From these findings, it would seem that additional factors are most likely involved in the presence or absence of $D$. geminata cells and mucilage. For example, such factors could include the specific characteristics exhibited by each river section, modulated by the climatic change between the seasons of the year. In winter, the long rainy season and high current flow may well prevent the settlement of mucilage in these two short and fast flowing rivers; in contrast, during the short summer season, water flow is 

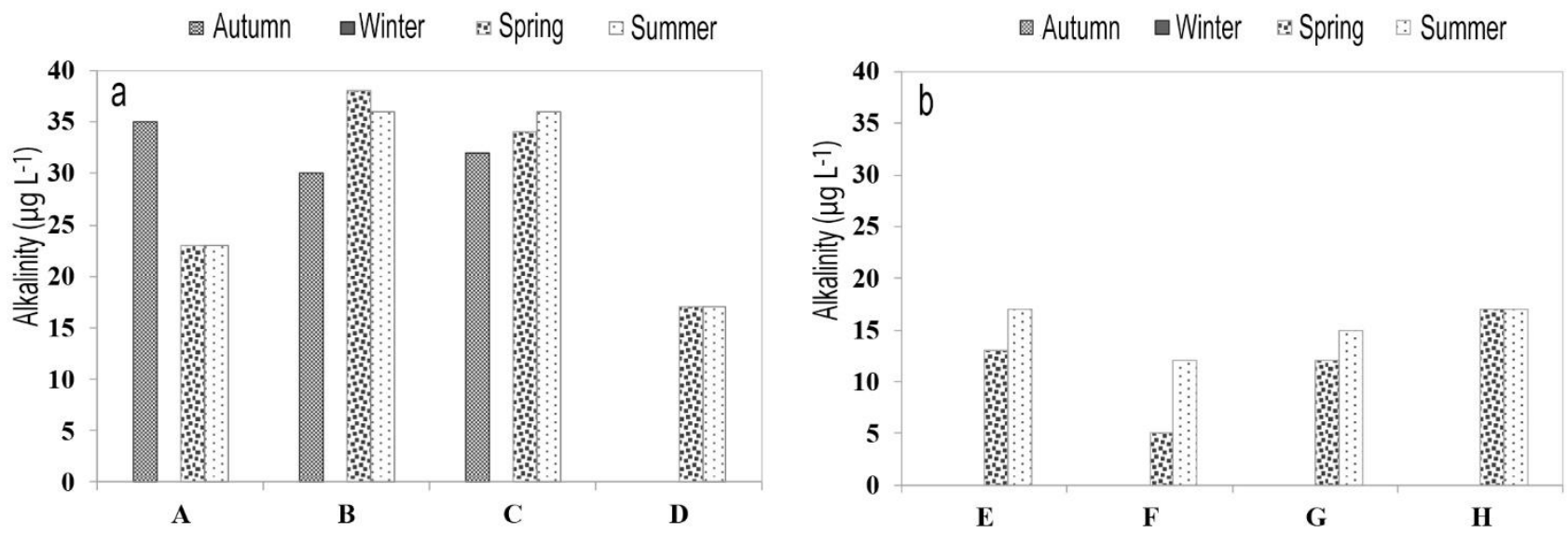

Figure 4. Alkalinity (mg L-1) by sampled sector and season. a) Petrohué River: A, B, C, D; b) Puelo River: E, F, G, H.
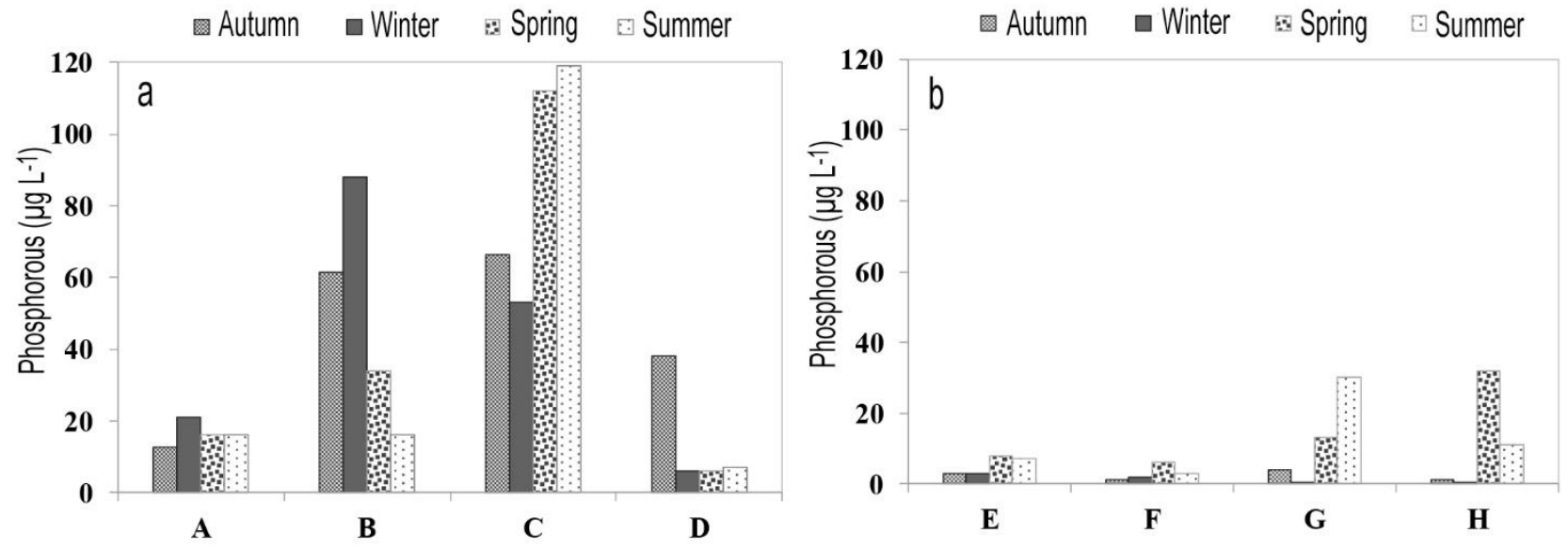

Figure 5. Phosphorous $\left(\mu \mathrm{g} \mathrm{L}^{-1}\right)$ in water by sampled sector and season. a) Petrohué River: A, B, C, D; b) Puelo River: E, $\mathrm{F}, \mathrm{G}, \mathrm{H}$.
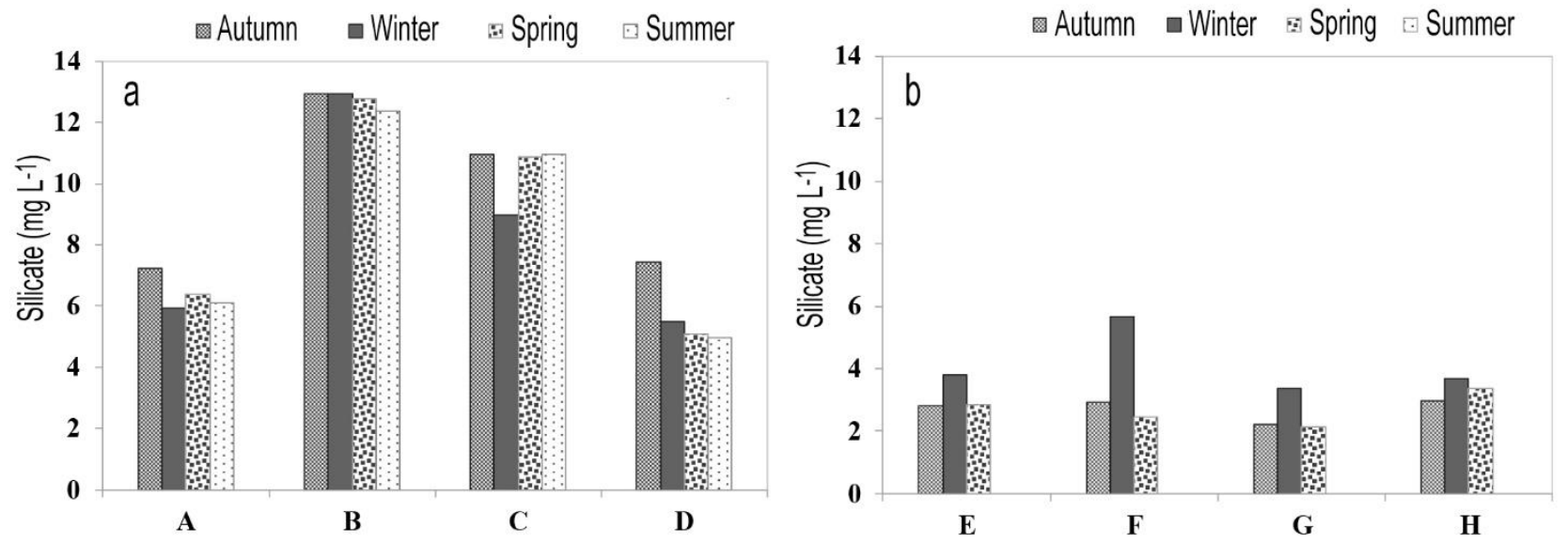

Figure 6. Silicate $\left(\mathrm{mg} \mathrm{L}^{-1}\right)$ in water by sampled sector and season. a) Petrohué River: A, B, C, D; b) Puelo River: E, F, G, H.

reduced, water temperature is higher, and there are more extended hours of daylight, which contribute to an increase in D. geminata blooms intensity. Diffe- rences between river sections in terms of vegetation and current velocity also seem to have a direct effect on the abundance of D. geminata. Having evaluated physical, 

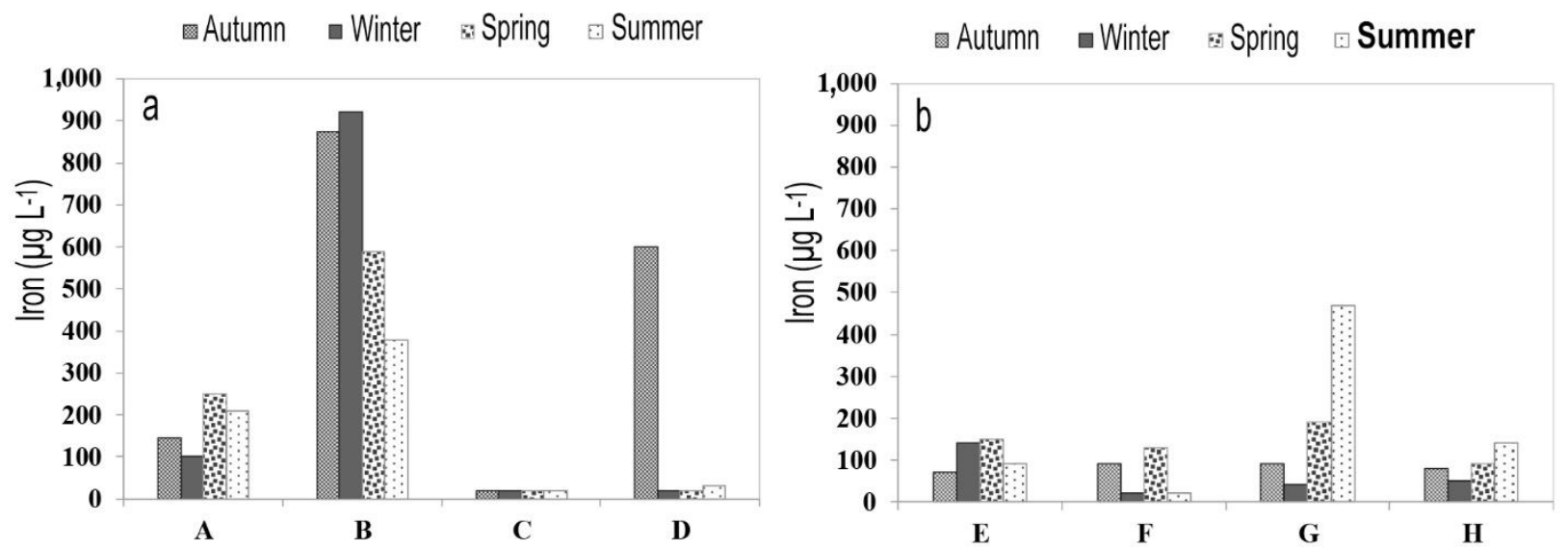

Figure 7. Iron $\left(\mu \mathrm{g} \mathrm{L}^{-1}\right)$ in water by sampled sector and season. a) Petrohué River: A, B, C, D; b) Puelo River: E, F, G, H.

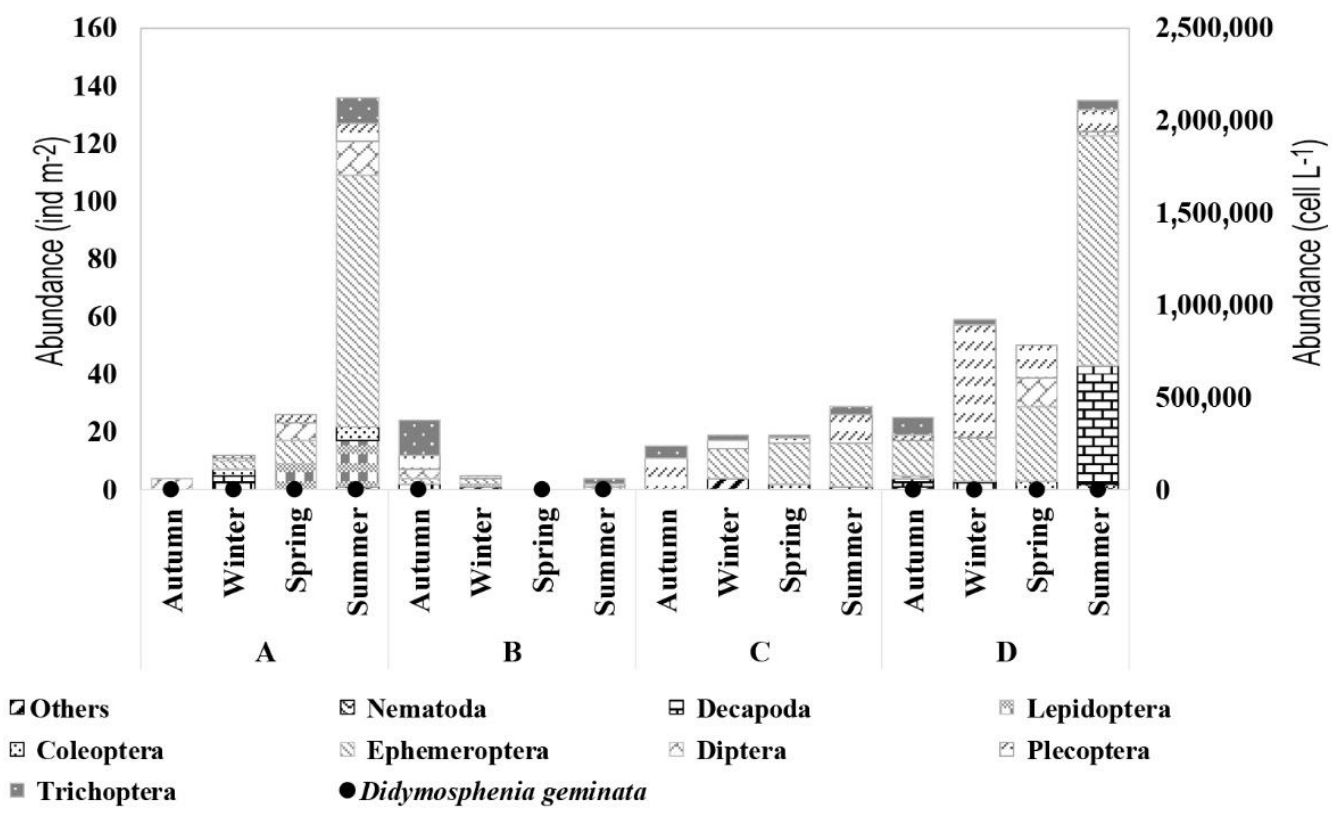

Figure 8. The abundance of macroinvertebrates in the substrate, by sector and seasonality in Petrohué River, concerning Didymosphenia geminata abundance (black dot). Sampled sectors: A, B, C, D.

water quality, and nutrient factors, James (2011) concluded that the availability and intensity of incident light was one of the most important factors that could potentially influence the presence of $D$. geminata colonies. Such a difference in light availability could, therefore, explain, in part, the differences recorded in $D$. geminata's mucilage abundance between both rivers and between sections within individual rivers.

The Puelo River is a long, wide and deep river, with a higher water velocity compared to the Petrohué River, which has narrower stream reaches, a denser canopy cover and restricted light abundance. It could well explain the reduced abundance of $D$. geminata cells and the absence of mucilage. Another factor that seems to determine a reduced presence of $D$. geminata coverage is the steep stream gradient. According to James (2011), streams with $>30 \%$ canopy cover and relatively steep stream gradients $(>1 \%)$ were found to be less susceptible to infestation by $D$. geminata colonies. In this study, the stream gradient was not measured for either river. However, as noted previously, the concentration of oxygen in the Petrohué River was higher than in the Puelo River, even though the water velocity was higher in the Puelo compared to the Petrohué. 


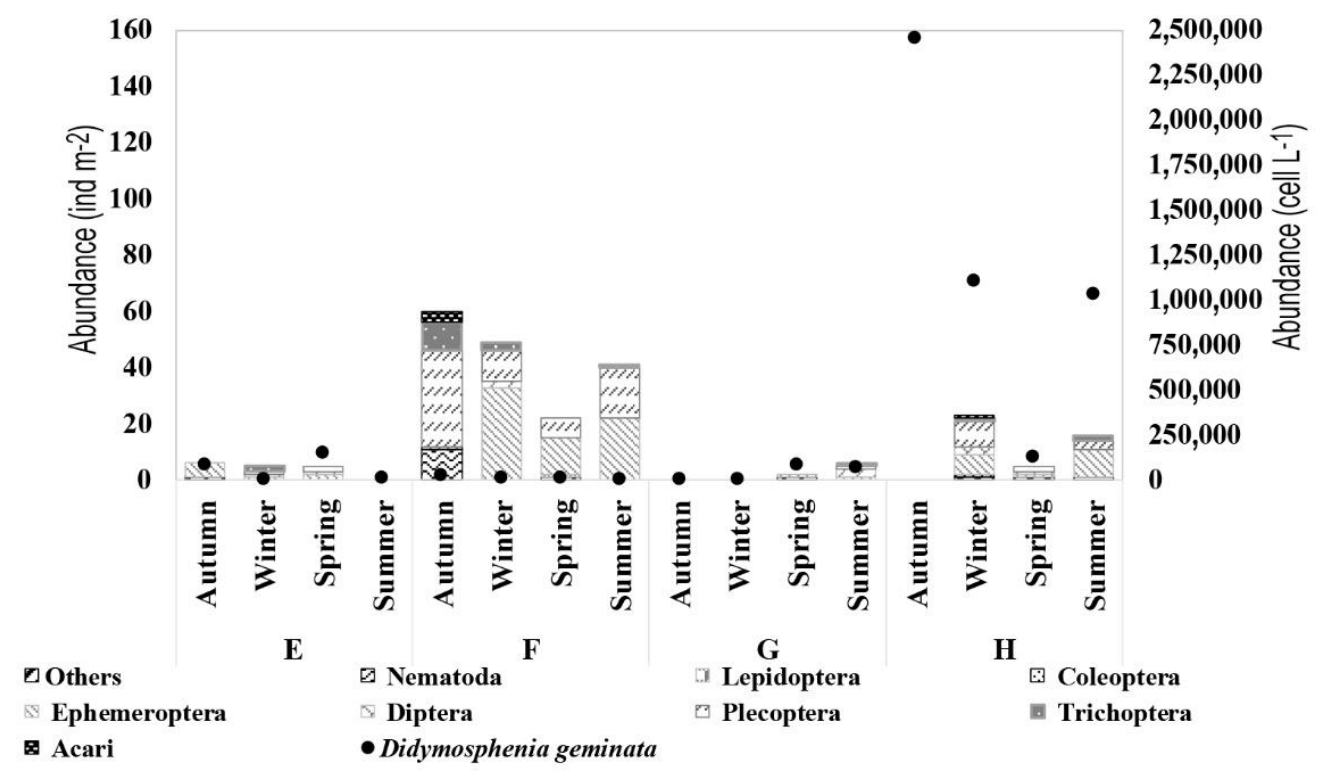

Figure 9. The abundance of macroinvertebrates in the substrate, by sector and seasonality in Puelo River, in relation to Didymosphenia geminata abundance (black dot). Sampled sectors: E, F, G, H.

Although historical information on D. geminata distribution is sparse, it was widely thought that expansion of $D$. geminata populations into new areas is associated with increased tolerance to environmental conditions (Kawecka \& Sanecki, 2003; Spaulding \& Elwell, 2007). Surveys in the western USA found that D. geminata occurred in water temperatures ranging from 4 to $27^{\circ} \mathrm{C}$ (Stoddard et al., 2005). In this study, the temperature ranged between 8.6 and $14.4^{\circ} \mathrm{C}$ in the Petrohué River and between 5.9 and $18.1^{\circ} \mathrm{C}$ in the Puelo River. D. geminata has also been observed across a range of water conductivities $\left(0-650 \mu \mathrm{mho}^{-1}\right)$ and acid neutralizing capacity (ANC, 0-6,000), although it occurred most frequently in water with conductivities

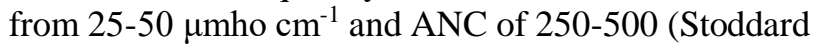
et al., 2005). In this study, the conductivity ranged

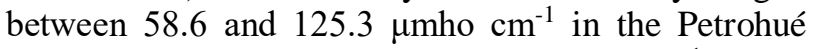

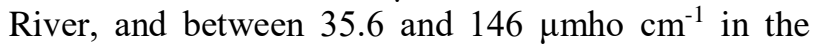
Puelo River.

It has previously been reported that $D$. geminata occurs in waters with $\mathrm{pH}$ values above 7 and that it is frequently observed in waters with a $\mathrm{pH}$ around 7.5. In this study, the $\mathrm{pH}$ in the Petrohué River ranged between 5.8 and 8.8, while in Puelo River, where D. geminata is present, the $\mathrm{pH}$ ranged between 5 and 7.1. In this study, a correlation was not found between invertebrate abundance with the presence of $D$. geminata, at differences of Ladrera et al. (2015) who reported that in river sections with high presence of $D$. geminata, the abundance of invertebrates is lower.

The overall conclusion of the research carried out by James (2011), has shown that susceptibility to $D$. geminata colonization in streams depends on stream width, gradient and canopy cover characteristics. Narrower streams, with a denser canopy cover and a steeper gradient, are less likely to experience growths of D. geminata. Such a situation was observed in sector $\mathrm{C}$ of the Petrohué River, where $D$. geminata cells were not recorded. This river section contained a dense canopy cover, which prevented efficient light penetration, in contrast to the other sites sampled during the study.

It is important to point out that to date, it has not been possible to control or eradicate Didymo in any of the countries where it is present. According to the results obtained and the literature consulted throughout this study, it can be concluded that the Puelo River has physicochemical characteristics ideal for the presence of Didymo, accompanied by a proliferation of dense mucilage. In contrast, on the Petrohué River, despite the presence of $D$. geminata cells, no incidence of mucilage was recorded. It may well be that the high concentrations of total phosphorus present in the Petrohué River, are acting as a limiting factor in the formation of the dense concentrations of mucilage, which typically characterizes the Didymo plague.

\section{ACKNOWLEDGMENTS}

We are grateful to María José Paredes, Ramiro Bahamonde and Daniel Muñoz for valuable help with the field work. This research was carried out under the framework of the project 15BP-45372, supported by CORFO, Chile. 


\section{REFERENCES}

Asprey, G.F., Benson-Evans, K. \& Furet, J. 1964. A contribution to the study of South American freshwater phytoplankton. Gayana Botánica, 10: 1-18.

Battarbee, R. 1986. Diatoms analysis. Handbook of Holocene palaeoecology and palaeohydrology. John Wiley \& Sons, New York, pp. 527-570.

Beville, S.T., Kerr, G.N. \& Hughey, K.F.D. 2012. Valuing impacts of the invasive alga Didymosphenia geminata on recreational angling. Ecological Economics, 82: 110.

Beamud, G., Baffico, G. \& Diaz, M. 2013. First record of the invasive algae Didymosphenia geminata in the Lake Nahuel Huapi: Argentina, Patagonia. Revista Chilena de Historia Natural, 86: 493-496.

Blanco, S. \& Ector, L. 2009. Distribution, ecology, and nuisance effects of the freshwater invasive diatom Didymosphenia geminata (Lyngbye) M. Schmidt: a literature review. Nova Hedwigia, 88: 347-422.

Bothwell, M. \& Kilroy, C. 2011. Phosphorus limitation of the freshwater benthic diatom Didymosphenia geminata determined by the frequency of dividing cells. Freshwater Biology, 56: 565-578.

Bothwell, L. \& Spaulding, M.L. 2008. Proceedings of the 2007 international workshop on Didymosphenia geminata. Canadian Technical Report of Fisheries and Aquatic Sciences, 2795: 96 pp.

Bothwell, M., Taylor, B. \& Kilroy, C. 2014. The Didymo story: the role of low dissolved phosphorus in the formation of Didymosphenia geminata blooms. Diatom Research, 29: 229-236.

Bothwell, M.L., Kilroy, C., Taylor, B.W., Ellison, E.T., James, D.A., Gillis, C.A., Bladon, K.D. \& Silins, U. 2012. Iron is not responsible for Didymosphenia geminata bloom formation in phosphorus-poor rivers. Canadian Journal of Fisheries and Aquatic Sciences, 69: 1723-1727.

Díaz, C., Molina, X. \& Montecino, V. 2011. Manual para el monitoreo e identificación de la microalga bentónica Didymosphenia geminata. Subsecretaría de Pesca, Valparaíso. [http://www.subpesca.cl/portal/618/articles-80177_documento.pdf]. Reviewed: 13 September 2018.

Domozych, D.S., Toso, M. \& Snyder, A. 2010. Biofilm dynamics of the nuisance diatom, Didymosphenia geminata (Bacillariophyceae). Nova Hedwigia, 136: 249-259.

Gretz, M.R. 2008. The stalks of Didymo. In: Bothwell, M.L \& Spaulding, S.A. (Eds.). Proceedings of the 2007 International Workshop on Didymosphenia geminata. Canadian Technical Report of Fisheries and Aquatic Sciences, 2795.
James, D.A., Bothwell, M.L., Chipps, S.R. \& Carreiro, J. 2015. Use of phosphorus to reduce blooms of the benthic diatom Didymosphenia geminata in an oligotrophic stream. Freshwater Science, 34(4): 12721281. doi: $10.1086 / 683038$.

James, D.A., Mosel, K. \& Chipps, S.R. 2014. The influence of light, stream gradient, and iron on Didymosphenia geminata bloom development in the Black Hills, South Dakota. Hydrobiologia, 721: 117127.

James, D.A. 2011. The influence of Didymosphenia geminata on fisheries resources in the Black Hills of South Dakota. Thesis Doctor of Philosophy, South Dakota State University, South Dakota, 190 pp.

Kawecka, B. \& Sanecki, J. 2003. Didymosphenia geminata in running waters of southern Poland symptoms of change in water quality? Hydrobiologia, 495: 193-201.

Kilroy, C. \& Unwin, M. 2011. The arrival and spread of the bloom-forming, freshwater diatom, Didymosphenia geminata, in New Zealand. Aquatic Invasions, 6: 249-262.

Kilroy, C., Biggs, B., Blair, N., Lambert, P., Jarvie, B., Dey, K., Robinson, K. \& Smale, D. 2005. Ecological studies of Didymosphenia geminata. National Institute of Water and Atmospheric Research, New Zealand. Client Report: CHC2005-123, NIWA Project: MAF05505.

Kirkwood, A.E., Jackson, J. \& McCauly, E. 2009. Are dams' hotspots for Didymosphenia geminata blooms? Freshwater Biology, 54: 1856-1863.

Kirkwood, A.E., Shea, T., Jackson, L.J. \& McCauley, E. 2007. Didymosphenia geminata in two Alberta headwater rivers: an emerging invasive species that challenges conventional views on algal bloom development. Canadian Journal of Fisheries and Aquatic Sciences, 64: 1703-1709.

Ladrera, R., Gomà, J. \& Prat, N. 2016. Regional distribution and temporal changes in density and biomass of Didymosphenia geminata in two Mediterranean river basins. Aquatic Invasions, 11(4): 355-367. doi: 10.3391/ai.2016.11.4.02.

Ladrera, R., Gomà, J. \& Prat, N. 2018. Effects of Didymosphenia geminata massive growth on stream communities: smaller organisms and simplified food structure. Plos One 13(3): e0193545. doi: 10.1371/ journal.pone.019345.

Ladrera, R., Rieradevall, M. \& Prat, N. 2015. Massive growth of the invasive algae Didymosphenia geminata associated with discharges from a mountain reservoir alters the taxonomic and functional structure of macroinvertebrate community. River Research and Applications, 31(2): 216-227. doi: 10.1002/rra.2731.

Lyngbye, H.C. 1819. Tentamen Hydrophytologiae Danicae Continens omnia Hydrophyta Cryptogama 
Daniae, Holsatiae, Faeroae, Islandiae, Groenlandiae hucusque cognita, Systematice Disposita, Descripta et iconibus illustrata, Adjectis Simul Speciebus Norvegicis. Hafniae, Copenhagen.

McCafferty, W.P. 1981. Aquatic entomology. The fisherman's and ecologist's guide to insects and their relatives. Jones and Bartlett Publishers, Massachusetts.

Montecino, V., Molina, X., Kumar, S., Castillo, M.L. \& Bustamante, R.O. 2014. Niche dynamics and potential geographic distribution of Didymosphenia geminata (Lyngbye) M. Schmidt, an invasive freshwater diatom in southern Chile. Aquatic Invasions, 9(4): 507-519.

Montecino, V., Molina, X., Bothwell, M., Muñoz, P., Carrevedo, M.I., Salinas, F., Kumar, S., Castillo, M.L., Bizama, G. \& Bustamante, R.O. 2016. Spatio temporal population dynamic of the invasive diatom Didymosphenia geminata in central-southern Chilean rivers. Science of the Total Environment, 568: 1135-1145.

Palma, A. 2013. Guía para la identificación de invertebrados acuáticos. [http://www2.udec.cl/ lpalma/ Palma2013_Guia_identificacion_Macroinvertebrados _preview.pdf]. Reviewed: 15 September 2018.

Patrick, R. \& Reimer, C.W. 1966. The diatoms of the United States. Monographs - Academy of Natural Sciences of Philadelphia, 1(13): 1-688.

Rivera, P. 1983. A guide for references and distribution for the class Bacillariophyceae in Chile between $18^{\circ} 28^{\prime} \mathrm{S}$ and $58^{\circ} \mathrm{S}$. Bibliotheca Diatomologica, 3: 1386.

Sastre, V., Santinelli, N.H., Bauer, G.A., Ayestarán, M.G. \& Uyua, N. 2013. First record of the invasive diatom Didymosphenia geminata (Lyngby) Schmidt in a Patagonian Andean river of Argentina. BioInvasions Records, 2(1): 11-17.

Segura, P. 2011. A slimy invader blooms in the rivers of Patagonia. Science, 331: 17-18.

Received: 14 November 2018; Accepted: 23 May 2019
Sherbot, D.M.J. \& Bothwell, M.L. 1993. Didymosphenia geminata (Gomphonemaceae). A review of the ecology of $D$. geminata and the physicochemical characteristics of endemic catchments on Vancouver Island. National Hydrology Research Institute (NHRI) Contribution 93005, Saskatoon.

Spaulding, S. \& Elwell, L. 2007. Increase in nuisance blooms and geographic expansion of the freshwater diatom Didymosphenia geminata: U.S. Geological Survey Open-File Report 2007-1425, 38 pp.

Stoddard, J.L., Peck, D.V., Olsen, A.R., Paulsen, S.G., Van Sickle, J., Herlihy, A.T., Kaufmann, P.R., Hughes, R.M., Whittier, T.R., Lomnicky, G., Larsen, D.P., Peterson, S.A. \& Ringold, P.L. 2005. Ecological assessment of western streams and rivers. U.S. Environmental Protection Agency, Corvallis.

Sundareshwar, P.V., Upadhayay, S., Abessa, M., Honomichl, S., Berdanier, B., Spaulding, S.A., Sandvick, C. \& Trennepohl, A. 2011. Didymosphenia geminata: algal blooms in oligotrophic streams and rivers. Geophysical Research Letters, 38(10). doi: 1029/2010GL046599

Throndsen, J. 1978. Preservation and storage. In: Sournia, A. (Ed.). Phytoplankton manual. UNESCO, Paris, pp. 69-74.

Wells, R., Duncan, M. \& Clearwater, S.J. 2007. Takaka river Didymo elimination feasibility study. National Institute of Water and Atmospheric Research, Client Report HAM2007-08, Hamilton.

Whitton, B.A. \& Ellwood, N.T. 2008. Growth and nutrient ecology of Didymosphenia in British Isles and other European countries. In: Bothwell, M.L \& Spaulding, S.A. (Eds.). Proceedings of the 2007 International Workshop on Didymosphenia geminata. Canadian Technical Report of Fisheries and Aquatic Sciences 2795.

Whitton, B.A., Ellwood, N.T.W. \& Kawecka, B. 2009. Biology of the freshwater diatom Didymosphenia geminata: a review. Hydrobiologia, 630: 1-37. 